ROCZNIKI HUMANISTYCZNE

Volume 67, issue 1 - 2019

SELECTED PAPERS IN ENGLISH

DOI: http://dx.doi.org/10.18290/rh.2019.67.1-8en

\title{
POLISH LITERATURE IN ISRAEL: BETWEEN THE MEMORY OF EUROPE AND A NEW LIFE
}

\section{LITERATURE OF THE "GREAT RELOCATION”}

In my article I suggest looking at Polish literature in Israel $^{1}$ as literature of the "great relocation" - that is, literature connected with migrations and written by migrants. Irrespective of any other possible interpretations ${ }^{2}$ texts written in Israel in the languages of the Diaspora-and connected with all the waves of Aliyah-may be treated in the broadest cultural interpretation as works that are a response to the experience of territorial relocation and of the functioning between the different cultures ${ }^{3}$ that are connected with it.

Prof. dr. hab. Eugenia Prokop-Janiec-Jagiellonian University, Faculty of Polish Studies, Department of Anthropology of Literature and Cultural Studies; e-mail: eugenia.prokopjaniec@uj.edu.pl

The Polish version of the article was published in Roczniki Humanistyczne vol. 64, issue 1 (2016).

${ }^{1}$ On the notion "Polish literature" in Israel see Karolina FAMUlSKA-CIESIELSKA, "Wstęp" (Introduction), in Karolina FAMULSKA-CIESIELSKA, Sławomir J. ŻUREK, Literatura polska w Izraelu. Leksykon (Polish Literature in Israel. A Lexicon) (Kraków-Budapest: Austeria, 2012), 5-6.

${ }^{2}$ Jacek Leociak thinks that "Literature written in Israel in the Polish language-beside literature written in Poland and in emigration-constitutes, as it were, the third state of matter" (Jacek LeOCiAK, "Na obu brzegach" (On Both Banks), Nowe Ksiażki no 3 (1994): 70). In turn, Alina Molisak points to the presence of the exile narrations in Polish literature written in Israel: see Alina MolisaK, "Narracje o wygnaniu w literaturze polskiej w Izraelu po roku 1948" (Narrations About Exile in Polish Literature in Israel After 1948), in Pisarz na emigracji: mitologie, style, strategie przetrwania (A Writer in Exile: Mythologies, Styles, Survival Strategies), eds. Hanna Gosk, Andrzej St. Kowalczyk (Warsaw: Elipsa, 2005).

${ }^{3}$ Marcel Goldman treats migration as an experience of a generation: "My generation is a replanted one. In the case of the immigration of Polish Jews to Israel it was replanting from the Polish soil to the sands of Israel. Everybody tried to take root. The results of course were different for each individual. (Marcel Goldman, A w nocy przychodza myśli [And at Night Thoughts Come] (Kraków: Wydawnictwo Signo, 2012), 13.) 
In my description of the phenomenon I would like to refer to certain findings included in the studies of Polish migration narrations of the $19^{\text {th }}$ and $20^{\text {th }}$ centuries. Pointing especially to the existence of a particular dialectic of settlers' and resettlers' narrations seems to me to be inspiring ${ }^{4}$. Settlers' stories are characterized by focusing on the present and evaluating the settling positively, which is motivated, among other things, by ideological reasons, especially by the imperative of "heroic territorial and cultural regaining" . On the other hand, narrations used by resettlers are first of all directed to the past, towards what has been lost, and they draw the material from the sources of memory. In various historical circumstances, in various literature periods, and also at various stages of the work of particular authors, the relations between those two models of narration are different. The rhythm of focusing on the present or on the past, the rhythm of antinostalgia coming to the forefront, depends on a number of factors-including also autobiographical and political determinants.

Similar dialectics may be noticed in Polish literature in Israel, in which records of the experience of migration assume various shapes-from the ideologically marked Zionist story told by the pioneers (Józef Kornblum) to the existential narrative written by exiles (Stanisław Wygodzki). It has to be stressed that migrants' experiences are not only a significant topic in PolishIsraeli fiction, but also in Polish-Israeli poetry. And it is poetry that I am going to focus on in the present article, and especially on a certain form the record of settling in Eretz Israel and the memory of Europe and of the experience of being displaced assumes. What I mean here are works in which the images of a new life refer to the classical forms of Polish literature and assume the shape of paraphrases, travesties or parodies ${ }^{6}$ of its canonic texts.

Natan Gross, one of the authors who eagerly use inter-textual techniques in their works, characterizes his poem as "parodies, paraphrases, rhyming,

\footnotetext{
${ }^{4}$ Such a differentiation was suggested by Inga IwAsIów: "Hipoteza literatury neo-postosiedleńczej" (A Hypothesis of Neo-Post-Settler Literature), in Narracje migracyjne w literaturze polskiej XX I XXI wieku (Migration Narrations in Polish Literature of the $20^{\text {th }}$ and $21^{\text {st }}$ Centuries), ed. Hanna Gosk (Kraków: Towarzystwo Autorów i Wydawców Prac Naukowych Universitas, 2012.

${ }^{5}$ Inga Iwasıów, Rewindykacje. Kobieta czytająca dzisiaj (Regaining. A Reading Woman Today) (Kraków: Towarzystwo Autorów i Wydawców Prac Naukowych Universitas, 2002), 220.

${ }^{6}$ Karolina FAmulska-Ciesielska, Polacy, Żydzi, Izraelczycy. Tożsamość w literaturze polskiej w Izraelu (Poles, Jews, Israelis. Identity in Polish Literature in Israel) (Toruń: Wydawnictwo Naukowe UMK, 2008), 220-221, emphasizes the trend of pastiche and parody occurring in poetry in the Polish language written in Israel.
} 
mélange, macaronic tales, thickly interlarded with Hebraisms and Hebraic quotations, full of non-involuntary reminiscences"7 of Polish poetry. Similarly, Henryk Ritterman describes his works as literary paraphrases; he also indicates the satiation with Polish-Hebrew macaronics as the main feature of their language. ${ }^{8}$ Commentaries by both authors reveal the cultural heterogeneity of the texts that is already to be found at the language level (sometimes also at the level of the record using the Latin and Hebrew alphabets) and the genre level where absorption of Hebrew elements is exposed, as well as their roots in the tradition of Polish literature.

This interpretation made by the authors demands the introduction of a broader research context. Literary tradition may be treated as a symptom of cultural memory. From an individual perspective this tradition is connected first of all with this form of memory that-here I refer to the typology proposed by the German researcher Aleida Assman-is formed "in the course of education" (Bildungsgedächtnis) and joins an individual with a certain community or a region'. By paraphrasing, travestying, parodying Polish texts Polish-Israeli authors manifest an intentional bond with Polish literature and their memory of the Polish tradition. Using Hebrew elements they show, however, their conscious difference in its space and declare their affiliation with the Hebrew world. In both cultural areas that they evoke in this way they indeed reveal, however, their ambivalent position: a bond, and at the same

\footnotetext{
${ }^{7}$ Natan Gross, Co nam zostato z tych lat (What Is Left of Those Years) (Tel Aviv: 1971), 5. It has to be added that linguistic games in Gross's poems sometimes have not only a bilingual, but multilingual character, and Latin is added to Polish and Hebrew. See e.g. "Kalicyna. Toast na nominację Dra Bencjona Katza Rektorem Tel-Awiwskiego Uniwersytetu" (Kalicyna. A Toast to the Nomination of Dr Bencjon Katz for the Rector of the Tel Aviv University), in ibid., 28-33.

${ }^{8}$ Henryk Rit [H. Ritterman], Pan Tuwia i inne parafrazy literackie. Fraszki-humoreskifelietony (Mr Tuwia and Other Literary Paraphrases. Epigrams-Humorous SketchesFeuilletons), (Tel Aviv: "Hadfus Haklali," s.d.), 123.

${ }^{9}$ Aleida AsSMAnN, "Przestrzenie pamięci. Formy i przemiany pamięci kulturowej" (Erinnerungsräume: Formen und Wandlungen des kulturellen Gedächtnisses), in Pamięć zbiorowa i kulturowa. Wspótczesna perspektywa niemiecka (Collective and Cultural Memory. A Contemporary German Perspective), ed. Magdalena Saryusz-Wolska (Kraków: Towarzystwo Autorów i Wydawców Prac Naukowych "Universitas," 2009), 103. Ruth Eldar wrote about the significance of this type of memory as a reservoir of "the treasures of Polish literature": Wstrzasnać filarami światyni (To Shake the Pillars of the Temple) (Łódź: Młyn-Literackie Studio Wydawnicze, 2004), 9. The process of writing poems "of quotations" from the remembered classical texts may take the shape of an auto-thematic motif: see Łucja GLIKSMAN, "Fortepian" (The Piano), in Wiersze zebrane (Collected Poems) (Tel Aviv: Kontury, 2004), 83.
} 
time a difference, a continuation and a departure, a non-definite affiliation and a non-definite non-affiliation. ${ }^{10}$

As I have already mentioned, Gross and Ritterman belong to a broader circle of Polish-Israeli poets in whose work inter-textuality plays an important role, and the forms of paraphrase, transposition or parody belong to their basic repertoire of genres. Łucja Gliksman, Ruth Eldar, Marcel Goldman and Jehuda Knobler may also be included in this group. The circle of Polish tradition referred to in their poetry includes the names of Adam Mickiewicz, Juliusz Słowacki, Maria Konopnicka, Stanisław Wyspiański, Tadeusz Boy-Żeleński, Leopold Staff, Julian Tuwim, Antoni Słonimski. ${ }^{11}$ Thus, as may be seen, the circle is made up of canonic authors of the $19^{\text {th }}$ century and of the interwar literature. It also cannot be overlooked that paraphrases and reminiscences of Mickiewicz's works, and particularly of Pan Tadeusz, ${ }^{12}$ are especially frequent in Polish-Israeli poetry.

\section{PARAPHRASE, PARODY, TRAVESTY}

As is well known, paraphrase, parody and travesty are literary texts that, through features of their own structure, point to other texts, ${ }^{13}$ revealing and emphasizing in this way their connections to them. One of the basic functions of these intertextual genres is interpretation and reinterpretation of

\footnotetext{
${ }^{10}$ The motif of affiliation/non-affiliation appears in many Polish-Israeli lyrical poems: Ida HENEFELD-Ron, "Droga do domu" (The Way Home), in Wczorajsze jutro: wiersze z Izraela (Yesterday's Tomorrow: Poems from Israel) (London: Oficyna Poetów i Malarzy, 1979), 39. I took the formula of affiliation/non-affiliation from Marcel Goldman's poetry.

${ }^{11}$ It is worth mentioning that a similar choice of tradition is characteristic of the current of paraphrases and parodies in Polish émigré poetry: Marian Hemar, Liryki. Satyry. Fraszki, (Lyrical Poems. Satires. Epigrams) (London, 1988). It has to be added that, besides the literary canon in Polish-Israeli poetry, folklore (Ł. Gliksman) and sometimes pop-culture texts, mainly those of songs (J. Knobler), are also referred to. On the popularity of J. Tuwim's poetry see Ruth ELDAR, Ukryte skarby (The Hidden Treasures) (Łódź: Biblioteka “Tygla Kultury,” 2014), 31-32. Paraphrases and reminiscences of Tuwim's poetry were dealt with in an independent study: Karolina FAMULSKA-CIESIELSKA, "Miejsce twórczości i postaci Juliana Tuwima w literaturze polskiej w Izraelu" (The Rank of Julian Tuwim's Work and Figure in Polish Literature in Israel), in Żydowskie konteksty twórczości Juliana Tuwima (Jewish Contexts of Julian Tuwim's Poetry), ed. Monika Adamczyk-Garbowska (Lublin: Wydawnictwo UMCS, 2015).

${ }^{12}$ In various contexts, for example, verses of Inwokacja (Invocation) are quoted: Jehuda KNOBLER, "Słońce nad Podbrzeziem" (The Sun over Podbrzezie), in Wspomnienie z lat ludobójczych 1939-1945 (A Recollection of the Genocidal Years 1939-1945) (Kraków: Miniatura, 2001), 72.

${ }^{13}$ Stanisław BaLbus, Między stylami (Between the Styles) (Kraków: Universitas, 1996), 16-17.
} 
literary tradition. ${ }^{14}$ What is more significant, works of this kind require special competences not only on the side of the author, but also on the side of the reader. Literary communication works only when the reader is able to recognize patterns and properly decipher the literary game that is played with him on various levels.

Those authors of Polish-Israeli paraphrases who use refined and complex techniques of literary references appeal to considerable cultural competences. Texts are often composed as a series of quotations, crypto-quotations or quasi-quotations. Sometimes such series refer the reader to one work or to the works of one author, ${ }^{15}$ elsewhere the quotations come from many sources with different authors, ${ }^{16}$ which makes the text similar to a montage or a bricolage and brings it close to a cento. (Nota bene, one of the frequent forms in the poetry of Polish-Israeli authors are poems introducing the scene of a school or home reading and "completing" in this way a kind of Polish canon library for the reader). ${ }^{17}$

Regarding the level of the style, Polish-Israeli poets intensively use multilingualism - usually they use Polish and Hebrew, but sometimes also Polish-Hebrew-English, French, Russian, $\mathrm{Arabic}^{18}$ or Latin. They introduce multilingual puns, anagrams and word plays, they also willingly use transformations of Polish and Hebrew phraseology and macaronic neologisms, as a rule building comic and parodic effects in this way.

The predilection to transgress language borders is an element of a broader process of transgressing cultural borders, and language games take part in the practice of cultural translation. The relationship between the literary model and its paraphrastic or parodist transformation opens a space for searching for and finding what is similar, close or common in what is different. Ethically oriented contemporary theories of translation-e.g. Lawrence Venuti's conception-emphasize, however, that searching for similarities between languages and cultures always occurs in confrontation with the

\footnotetext{
${ }^{14}$ Michał GŁOwIŃSKI, “O intertekstualności” (On Intertextuality), in Michał GŁOwIŃSKI, Intertekstualność, groteska, parabola (Intertextuality, Grotesque, Parable) (Kraków: Universitas, 2000), 14.

${ }^{15}$ Łucja Gliksman, "Mickiewicz," in Nostalgia (Nostalgy) (Olsztyn: Oficyna Druków Niskonakładowych, 1995), 6.

${ }^{16}$ Quotations from works by Słowacki and Mickiewicz are especially often combined.

${ }^{17}$ See Łucja Gliksman, Wiersze zebrane (Collected Poems), p. 80; Jehuda KNOBLER, "Słońce nad Podbrzeziem."

${ }^{18}$ See Henryk Rit [H. RitTERman], "Izraelskie Dziady" (The Israeli Forefathers' Eve) in Pan Tuwia, 34-46.
} 
zones of what is different and dissimilar ${ }^{19}$. Polish-Israeli paraphrases also activate that complex translational effect of similarity and difference. The mechanism that works here most generally may be described as the product of transfer, relocation and reinscription: an element that was created in defined historical and cultural conditions and functioned in a certain literary system is relocated ${ }^{20}$ outside its primary context and then located and inscribed into a new historical-cultural environment. Hence its relocation is necessarily connected with transformation, modification, inaccurate assimilation. In the new cultural position, however, it reveals its genealogy, that is, its original position ${ }^{21}$.

By making a Polish-Jewish cultural transfer Israeli authors refer to the tradition dating back to at least the middle of the $19^{\text {th }}$ century and present both in Polish and in Polish-Jewish literature. I will briefly remind the reader that the first known Polish-Jewish paraphrases of canonical Polish literature texts come from the middle of the $19^{\text {th }}$ century. As early as that references to Adam Mickiewicz's works played a special role among them ${ }^{22}$. Such poems as "To an Israeli Mother" (a paraphrase of the poem "To a Polish Mother") were not only imitations of a Polish model but also its peculiar Jewish approving continuation: the Polish mother proved to be an inspiring model for the Israeli mother. A figure that was symbolic for the Polish national mythology was taken over and "translated" into the cultural-social Jewish reality and then inscribed into an assimilatory, Polonization project:

Oh, Israeli! When for us the dawn

Shines today after ages of attempts and suffering,

The hand of Providence puts

Responsibility for happiness of your children.

$[\ldots]$

\footnotetext{
${ }^{19}$ Lawrence Venuti, Scandals of Translations. Towards the Ethics of Difference, London: Routledge, 1998.

${ }^{20}$ On the connection between translation and relocation see Doris BACHMANN-Medick, "Translational turn" in Cultural Turns. Nowe kierunki w naukach o kulturze (Cultural Turns. New Trends in Cultural Studies), translated into Polish by Krystyna Krzemieniowa (Warsaw: Oficyna Naukowa, 2012), 292.

${ }^{21}$ I refer here to S. Balbus's findings, Między stylami (Between the Styles), 29.

${ }^{22}$ See Henryk Merzbach, "Do matki Izraelki" (To an Israeli Mother), in Żydzi w Polsce. Antologia literacka (Jews in Poland. An Anthology of Literature), ed. Henryk Markiewicz (Kraków: Towarzystwo Autorów i Wydawców Prac Naukowych "Universitas," 1997); Marian Hemar, "Parafraza" (A Paraphrase), in Izrael w poezji polskiej. Antologia (Israel in Polish Poetry. An Anthology), selected and edited by Jan Winczakiewicz (Paris: Instytut Literacki, 1958).
} 
Teach your son love and faith;

Let him go forward under the sign of progress,

Under the sign of work, learning, sacrifice,

Let him remain a Pole-living in Poland. ${ }^{23}$

The twentieth century Polish-Jewish references to Mickiewicz's poetry, and especially those of the interwar period, had a radically different character and function. First of all, they used a strategy of rewriting the Polish canon critically using its patterns in a subversive way and revealing the distances and differences. For example, in "Jankiel the Cymbalist" by Maurycy Szymel the vicissitudes of the protagonist of Mickiewicz's epic poem are polemically complemented and developed. In a work that, in a peculiar way, closes the Jewish motif in Pan Tadeusz, scenes are added of excluding the Jewish player from the Polish world:

—Jankiel, Jankiel, my brother in bitterness,

Here you are going, quiet, to this nightingale's twilight

And you do not remember that moment or that offence,

When Mr. Gerwazy aimed - at you — with his sword

When with his face flushing with blood he cried: 'Off with you, Jew,

Do not stick your neck out, it is not about you'.

[...]

-My Jankiel, oh, what for we play at wedding parties,

When we are never going to find a friend-

At you, at me, at all, ignoring everybody,

Gerwazy will always aim with his sword...

We cannot escape shame, blood and martyrdom! $!^{24}$

The significance of these additions is in overt opposition to Mickiewicz's solidaristic position and offers a pessimistic correction to the optimistic finale of his great poem ${ }^{25}$. Hence Szymel's work is a critical Jewish commentary reinterpreting Polish tradition.

\footnotetext{
${ }^{23}$ Henryk MerzBaCh, Do Matki Izraelki (To an Israeli Mother), 243.

${ }^{24}$ Maurycy SzYMEL, "Jankiel Cymbalista" (Jankiel the Cymbalist), in Międzywojenna poezja polsko-żydowska. Antologia (Interwar Polish-Jewish Poetry. An Anthology), selected, provided with explanations and an introduction, and edited by Eugenia Prokop-Janiec (Kraków: Towarzystwo Autorów i Wydawców Prac Naukowych "Universitas," 1996), 285.

${ }^{25}$ In still another function, the Polish-Jewish transfer was used by Polish authors. The tendency towards revealing the disproportion and hierarchical difference between the Polish and Jewish worlds was the dominating one, and the texts above all had a ludic-satirical function. See Włodzimierz WYsocki, "Nowe Dziady. Żarcik poetycki” (New Forefathers' Eve. A Poetical Joke), in Izrael w poezji polskiej (Israel in Polish Poetry), 301; Kazimierz ŻYGULSKI, Wspólnota śmiechu. Studium socjologiczne komizmu (The Community of Laughter. A Sociological Study of Humor) (Warsaw: Państwowy Instytut Wydawniczy, 1985), 110-111.
} 


\section{POLISH-ISRAELI SETTLERS'}

\section{AND RESETTLERS NARRATIVES}

Analyzing the games with the Polish literary tradition in Polish-Israeli poetry I would like to focus on the paraphrases of Pan Tadeusz that are particularly interesting for me-especially because of the problem of migrants' literature and migrants' narratives. As is well known, Mickiewicz's epic poem (1834) is a work "marked with exile", it is an "emigrant's dream" nostalgic, looking back at the past, relying on memory. The "Invocation" and "Epilogue" of the work are, for Polish literature, "a model of exile declarations repeated by each of the next generations ${ }^{27}$ of authors writing about the "lost places" of their childhood.

Probably the earliest—dating back to the middle of the $1950 \mathrm{~s}^{28}$ - PolishIsraeli paraphrase of Pan Tadeusz is Pan Tuwia, Or the Last Olim Invasion of Israel-Lithuania by the satirist Henryk Ritterman. The piece is a very ingenious (and funny) ${ }^{29}$ rewriting of the Polish nineteenth century "noblemen's story" into a story about today's Israel. A clerk of the Jewish Agency, Sochnut, residing in Paris, satisfied with his job, is the narrator of Pan Tuwia. The action takes place not far from Tel Aviv, at the home of a certain Szofet (in Poland a judge, and in Israel a businessman), where the young Tuwia, a reveler and not very diligent medicine student, comes:

${ }^{26}$ Alina WitKowsKa, “'Pan Tadeusz' emigracją naznaczony” (Pan Tadeusz Marked with Exile), in Trzynaście arcydzieł emigracyjnych (Thirteen Emigration Masterpieces), ed. Elżbieta Kiślak, Marek Gumkowski (Warsaw: Instytut Badań Literackich, 1996).

${ }^{27}$ Agnieszka CzajkowsKa, "Pan Tadeusz Konwicki(ego)” [Pan Tadeusz Konwicki('s)], in "Pan Tadeusz" i jego dziedzictwo: recepcja ("Pan Tadeusz" and its Heritage: Reception), ed. Bogusław Dopart (Kraków: Towarzystwo Autorów i Wydawców Prac Naukowych "Universitas," 2006), 237.

${ }^{28}$ The authors of the entry Ritterman-Abir Henryk in the lexicon Literatura polska w Izraelu (Polish Literature in Israel) are wrong in saying that the text was written at the beginning of the 1950s (FAMULSKA-CIESIELSKA, ŻUREK, Literatura polska $w$ Izraelu. Leksykon [Polish Literature in Israel. A Lexicon], 83). An allusion to F. Sagan's novel Hallo Sadness shows that it should be dated to the middle of the 1950's:

What books do you read? There are people today, my word,

Who only know about the checkbook

And think that Sagan is something to do with sago. What a mess!

They haven't even read "Boker tow, tristesse."

(RIT, Pan Tuwia, 146). The title of the novel is given here in the Hebrew-French macaronic form.

${ }^{29}$ This is how Ritterman's work is appreciated by, among others, Ryszard Löw, "Wielka przygoda polszczyzny" (The Polish Language's Great Adventure), in Maria LewiŃsKA, Przechowane stowa (The Preserved Words) (Tel Aviv: Instytut Polski w Tel Awiwie, 2008), 9. 
Mr Szofet is not a Sabra and from faraway countries

He brought respect for the local customs.

Once he was a clerk at a town, a town judge

Well-known in the Black-White-Stok province.

Until the German onslaught spurred him to act.

He felt to be a Zionist and hit the road. ${ }^{30}$

Szofet's home is full of guests: immigrants - the host's acquaintances and relatives hang around, watikim and olim discuss current politics, and the function of seneschal is performed by Gojski, a former officer in the Polish army. A comic effect is achieved by Ritterman primarily through a multilingual play on words and a translation of realities:

\footnotetext{
Among such fields, years before, in the Kingdom of Mapaj

On a little hill, in the Israeli Kłaj

There was a dwelling house, small, but tidy in every respect,

It had graceful pillars, like a woman's legs,

And a garage, and four limousines just beside it.

It is clear that the neighborhood is rich in cars.

The gate that's always open announces to the passers-by

That it is hospitable and invites all

Apart from relatives - immigrants (there are lots of them

Hanging about) and clerks from misrad mas hachnasa. ${ }^{31}$
}

The author humorously uses the differences and similarities of the types of protagonists, their social positions and behaviors, ingeniously finds Lithuanian-Israeli analogies of the topography, landscape, plant life, architecture, national symbols. For instance, the portraits of Polish national heroes mentioned in Mickiewicz's poem are replaced by the images of Zionist leaders, "Herzl, beautiful and somber, and Ben Gurion, his inseparable friend" (p. 125); instead of traditional Polish dishes Jewish delicacies are introduced, and hunting is replaced with a bridge tournament. Protagonists talk about writers famous in Europe, about popular music, new dances, film stars. I recapitulate these motifs in order to emphasize how this story in the Israel of the 1950's is far removed from the past and focused on the present, on local politics, modern customs, fashion and art. A reference to the Holocaust appears only in mentions of the "German onslaught," "German

\footnotetext{
${ }^{30}$ Henryk Rit [H. RitTerman], "Pan Tuwia, czyli ostatni najazd olim na Izrael-Litwę" (Pan Tuwia, Or the Last Olim Invasion of Israel—Lithuania), in Pan Tuwia, 128.

${ }^{31}$ Ibid., 125. The Hebrew term misrad mas hachnasa is explained in a footnote: the tax office.
} 
restitutions" (p. 142) and the origin of the Polish name of one of the protagonists who kept it from the documents that he had used during the war:

It is not always that his name was so. Speaking between us

He bought such papers during the occupation.

The Podkomorskis are proud of such ennoblement

And frighten people with the name coming from the gentry (p. 133).

The motif of Paris, the town of the exile that is so important for Mickiewicz, is replaced in Rit's poem by the motif of Paris, a metropolis that enraptures the newcomers with its attractions of modern life which it is easy to become drawn to. Instead of confessing the exile's sufferings, in Pan Tuwia cosmopolitan pleasures are described. It is also striking that contrary to previous authors, Ritterman completely releases his paraphrase from the context of Polish-Jewish relations ${ }^{32}$. Mickiewicz's text is treated as his own tradition, assimilated ${ }^{33}$, not tangled up in the history of inter-group contacts.

Another example of using motifs from Pan Tadeusz may be found in Natan Gross's poem "Hesio's Concert" written at the beginning of the 1970s. Gross paraphrases and contaminates various musical motifs taken from Mickiewicz's poem. The most important of them is Jankiel's concertJankiel is a Jewish cymbalist whose musical story presents the history of Poland in the $18^{\text {th }}$ and $19^{\text {th }}$ century: the history of the fall of the country, of the partitions, of the attempts at introducing reforms and the armed struggle for the rebirth of independence. ${ }^{34}$ Quotations and crypto-quotations of Mickiewicz's text are included by Gross in the rhyming account of a trip to Mount Carmel organized for a group of young Israelis that are accompanied

\footnotetext{
${ }^{32}$ It is worth adding that the author also paraphrased and parodied other works by Mickiewicz. In The Israeli Forefathers' Eve he changed, for example, the motif (taken from Part II of the drama) of communicating with spirits to jocular complaining about the Israeli supply troubles, bureaucracy, high taxes, and primarily to introducing the problem of migration and a satirical presentation of the relationship between the newcomers to the country and those who had settled there earlier and feel at home now. Rit, Pan Tuwia, 34-46.

${ }^{33}$ Dorota KoŁODZIEJCZYK, "Meta-fory, trans-lacje, hybrydy-tropy migracji" (Meta-phors, Trans-lations, Hybrids-the Tropes of Migration), in Narracje migracyjne $w$ literaturze polskiej XX i XXI wieku (Migrant Narratives in Polish Literature of the $20^{\text {th }}$ and $21^{\text {st }}$ Century), ed. Hanna Gosk (Kraków: Towarzystwo Autorów i Wydawców Prac Naukowych Universitas, 2012), 18.

${ }^{34}$ The motif is contaminated by Gross with the motif of Wojski's playing the horn to announce the end of the hunt introduced by the refrain:

"Suddenly he stopped, but kept the trumpet.

It seemed to everybody

That Hesio kept playing. And it was the echo that was playing"
} 
by a former student of a Hebrew secondary school in Kraków. It is he-once a trumpeter in the school orchestra-who, at his daughter's request, will play for the young sabras:

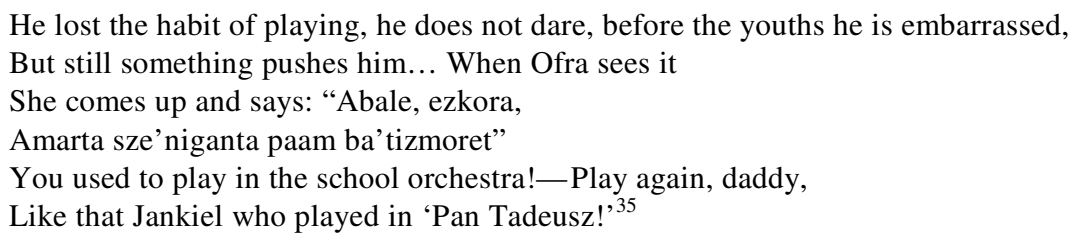

His musical story concerns the history of the Kraków school and Jewish Kraków from the time before the Holocaust. The trumpeter includes various musical forms in his concert: marches, Hasidic melodies, the Kraków trumpet signal. The signal played every hour from the spire of Saint Mary's Basilica is connected with a local medieval legend. In the $13^{\text {th }}$ century Kraków managed to defend itself against a Mongol attack, but the trumpeter was shot in the throat when sounding the alarm. It is his death that is symbolized by the sudden break off of the tune. This local musical symbol is also transformed by Gross into a symbol of the Holocaust and the end of the world of the Kraków Jews, forming in this way a bond between the Polish and Jewish memory. His "Hesio's Concert" is also a story about loss and memory. Standing on Mount Carmel the Jewish trumpeter recollects the Kraków of his childhood, bewailing the break-up of his school orchestra and the dispersing of his co-musicians, introducing in his concert a dialog of the times and space. The obstinately recurring echo of the tunes he had played is a trace of the past that reaches the young.

The motif of Jankiel's concert also returns several times in Łucja Gliksman's poems written in the 1990s. In them, Mickiewicz is first of all a guide for other poets of the exile. Following his example, however, they cannot evoke, like he did, the beauty, order and harmony of the world ${ }^{36}$ in their memories, and recollecting the past does not bring them relief and comfort:

We went even farther on the way of exile,

Recollecting and suffering and crying in secret ${ }^{37}$.

\footnotetext{
${ }^{35}$ Natan Gross, “Koncert Hesia” (Hesio's Concert), in Co nam zostało (What Is Left), 11.

${ }^{36}$ Czesław Miłosz interpreted Pan Tadeusz in this way, calling it "a theodicy, that is, a justification of the Creator-for He is the Creator of the Earth-garden" (Czesław MiŁosz, Ziemia Ulro [The Land of Ulro] (Kraków: Znak, 1994), 135).

${ }^{37}$ GLiksman, "Mickiewicz,” 31.
} 
From the perspective of the Holocaust Gliksman adds a new-ultimateending to the Jankiel motif: the player dies and his music is heard no more ("Jankiel's Concert").

\section{CONCLUSION}

In conclusion I will repeat the fact that Polish-Israeli paraphrases of Mickiewicz's works refer in a special way to the migration experience-by using the settlers' and resettlers' perspective, giving privileges to the present or allowing the past to speak. The use of canonic Polish literary models in the stories of the new life, inscribing the Israeli world and the signs of Hebrew culture in them, may be treated as a peculiar correlate of the experience of migration. And the fact that the canon of Polish literature is treated by Polish-Israeli authors as their own, assimilated tradition, may serve as an argument to support the opinion once expressed by the KrakówTel Aviv critic, historian and editor Ryszard Lwöw: Polish-Israeli literature belongs to the "great home of Polish literature." 38

\section{SELECTED BIBLIOGRAPHY}

Assmann, Aleida. "Przestrzenie pamięci. Formy i przemiany pamięci kulturowej" (Erinnerungsräume: Formen und Wandlungen des kulturellen Gedächtnisses). In Pamięć zbiorowa i kulturowa. Wspótczesna perspektywa niemiecka (Collective and Cultural Memory. A Contemporary German Perspective), ed. Magdalena Saryusz-Wolska. Kraków: Towarzystwo Autorów i Wydawców Prac Naukowych "Universitas,” 2009.

Balbus, Stanisław. Między stylami (Between the Styles). Kraków: Universitas, 1996.

ELDAR, Ruth. Wstrzasnać filarami świątyni (To Shake the Pillars of the Temple). Łódź: MłynLiterackie Studio Wydawnicze, 2004.

FAMUlska-CiesIElska, Karolina, Sławomir J. ŻUReK. Literatura polska w Izraelu. Leksykon (Polish Literature in Israel. A Lexicon). Kraków-Budapest: Austeria, 2012.

FAMUlSKA-CiESIElSKA, Karolina. "Miejsce twórczości i postaci Juliana Tuwima w literaturze polskiej w Izraelu." In Żydowskie konteksty twórczości Juliana Tuwima (Jewish Contexts in Julian Tuwim's Poetry), ed. Monika Adamczyk-Garbowska. Lublin: Wydawnictwo UMCS, 2015.

Famulska-Ciesielska, Karolina. Polacy, Żydzi, Izraelczycy. Tożsamość w literaturze polskiej w Izraelu (Poles, Jews, Israelis. Identity in Polish Literature in Israel). Toruń: Wydawnictwo Naukowe UMK, 2008.

\footnotetext{
${ }^{38}$ Ryszard Löw, “Kontury. Pismo. Autorzy. Tematy. Recepcja” (Contours. Writing. Authors. Subjects. Reception), in LEWIŃsKA, Przechowane stowa (Preserved Words), 92.
} 
Gliksman, Łucja. Wiersze zebrane (Collected Poems). Tel Aviv: Kontury, 2004.

GŁOWIŃSKI, Michał. Intertekstualność, groteska, parabola (Intertextuality, Grotesque, Parable). Kraków: Universitas, 2000.

Goldman, Marcel. A w nocy przychodzq myśli [And at Night Thoughts Come]. Kraków: Wydawnictwo Signo, 2012.

Gross, Natan. Co nam zostało z tych lat (What Is Left of Those Years). Tel Aviv, 1971.

Hemar, Marian. "Parafraza" (A Paraphrase). In Izrael w poezji polskiej. Antologia (Israel in Polish Poetry. An Anthology), selected and edited by Jan Winczakiewicz. Paris: Instytut Literacki, 1958.

Hemar, Marian. Liryki. Satyry. Fraszki, (Lyrical Poems. Satires. Epigrams). London, 1988.

IwASIów, Inga. "Hipoteza literatury neo-post-osiedleńczej” (A Hypothesis of Neo-Post-Settler Literature). In Narracje migracyjne w literaturze polskiej XX I XXI wieku (Migration Narrations in Polish Literature of the $20^{\text {th }}$ and $21^{\text {st }}$ Centuries), ed. Hanna Gosk. Kraków: Towarzystwo Autorów i Wydawców Prac Naukowych "Universitas," 2012.

IwASIów, Inga. Rewindykacje. Kobieta czytajaca dzisiaj (Regaining. A Reading Woman Today). Kraków: Towarzystwo Autorów i Wydawców Prac Naukowych Universitas, 2002.

KoŁodZIEJCZYK, Dorota. "Meta-fory, trans-lacje, hybrydy—-tropy migracji” (Meta-phors, Translations, Hybrids - the Tropes of Migration). In Narracje migracyjne w literaturze polskiej XX $i$ XXI wieku (Migrant Narratives in Polish Literature of the $20^{\text {th }}$ and $21^{\text {st }}$ Century), ed. Hanna Gosk. Kraków: Towarzystwo Autorów i Wydawców Prac Naukowych "Universitas," 2012.

LEOCIAK, Jacek. "Na obu brzegach” (On Both Banks). Nowe Książki no 3 (1994).

Löw, Ryszard. "Wielka przygoda polszczyzny" (The Polish Language's Great Adventure). In Maria LewińsKa. Przechowane stowa (The Preserved Words). Tel Aviv: Instytut Polski w Tel Awiwie, 2008.

MolISAK, Alina. "Narracje o wygnaniu w literaturze polskiej w Izraelu po roku 1948" (Narrations About Exile in Polish Literature in Israel After 1948). In Pisarz na emigracji: mitologie, style, strategie przetrwania (A Writer in Exile: Mythologies, Styles, Survival Strategies), eds. Hanna Gosk, Andrzej St. Kowalczyk. Warsaw: Elipsa, 2005.

Rit, Henryk [H. RitTerman]. Pan Tuwia i inne parafrazy literackie. Fraszki-humoreski-felietony (Mr Tuwia and Other Literary Paraphrases. Epigrams-Humorous SketchesFeuilletons). Tel Aviv: "Hadfus Haklali," 1951.

SzYMEL, Maurycy. "Jankiel Cymbalista" (Jankiel the Cymbalist). In Międzywojenna poezja polsko-żydowska. Antologia (Interwar Polish-Jewish Poetry. An Anthology), selected, provided with explanations and an introduction, and edited by Eugenia Prokop-Janiec. Kraków: Towarzystwo Autorów i Wydawców Prac Naukowych "Universitas," 1996.

Venuti, Lawrence. Scandals of Translations. Towards the Ethics of Difference. London: Routledge, 1998.

WitKowsKA, Alina. “'Pan Tadeusz’ emigracją naznaczony” (Pan Tadeusz Marked with Exile). In Trzynaście arcydzieł emigracyjnych (Thirteen Emigration Masterpieces), ed. Elżbieta Kiślak, Marek Gumkowski. Warsaw: Instytut Badań Literackich, 1996.

ŻYGULSKI, Kazimierz. Wspólnota śmiechu. Studium socjologiczne komizmu (The Community of Laughter. A Sociological Study of Humor). Warsaw: Państwowy Instytut Wydawniczy, 1985. 


\section{POLISH LITERATURE IN ISRAEL: \\ BETWEEN THE MEMORY OF EUROPE AND A NEW LIFE}

\section{Summary}

The article presents Polish literature in Israel as literature written by migrants: a response to the experience of being relocated and of functioning between different cultures. The subject of the analyses are the paraphrases, travesties and parodies of works by Adam Mickiewicz that are present in Polish-Israeli literature. Referring to the canon texts of Polish literature in them serves the recording of life in Israel. Using Polish literary patterns in stories about the new life and inscribing the Israeli world, as well as signs of Hebrew culture, into them is interpreted as a peculiar correlate of the experience of migration.

Key words: Polish literature in Israel; Polish poetry in Israel; migration narrations; migration experience; literary paraphrase.

Translated by Tadeusz Kartowicz

The preparation of the English version of Roczniki Humanistyczne and its publication in electronic databases was financed under contract no. 836/P-DUN/2018 from the resources of the Minister of Science and Higher Education for the popularization of science. 